\title{
Islas de las Californias, Colaboración Botánica: Islands of the Californias Botanical Collaborative
}

\author{
William Hoyer III ${ }^{1, *}$, John KNapP 2 , Denise Knapp 3 , DaVid MaZurkieWicZ ${ }^{4}$, \\ Ken Owen ${ }^{5}$, Luciana Luna-Mendoza ${ }^{6}$, and Kathryn McEachern ${ }^{7}$ \\ ${ }^{1}$ Naval Base Ventura County, ENV Division, 311 Main Road, Point Mugu, CA 93042 \\ ${ }^{2}$ The Nature Conservancy \\ ${ }^{3}$ Santa Barbara Botanic Garden, 1212 Mission Canyon Rd., Santa Barbara, CA 93105 \\ ${ }^{4}$ Channel Islands National Park, 1901 Spinnaker Dr., Ventura, CA \\ ${ }^{5}$ Channel Islands Restoration, 928 Carpinteria St. \#3, Santa Barbara, CA 93103 \\ ${ }^{6}$ Grupo de Ecología y Conservación de Islas, A.C., Ensenada, Mexico \\ ${ }^{7}$ U.S. Geological Survey, Western Ecological Research Center, Channel Islands Field Station
}

\begin{abstract}
After nearly 2 centuries of being negatively impacted, primarily by introduced mainland vertebrates, the unique flora and vegetation of the Islands of the Californias archipelago have been severely degraded. The botanical conservation challenges that lie ahead include the near extinction or extirpation of rare, endemic, and even common plant taxa; invasion of nonnative plants; near loss of unique island vegetation communities; and the degradation of a host of sites. These challenges are too large for any one entity to remedy alone. Many of the botanical resources impacted are found on multiple islands and cross political boundaries. The Islands of the Californias managers and their mainland partners have formalized a binational collaboration, the Islas de las Californias, Colaboración Botánica, or Islands of the Californias Botanical Collaborative (ICBC), to address these challenges more effectively and efficiently and thus achieve greater conservation success. The ICBC has identified and prioritized challenges in botanical resource management, taken actions to recover plant populations at risk and prevent future extinctions, developed tools to evaluate plant reintroductions, implemented quarterly meetings to share professional experiences, begun to develop tools for information and data sharing, and leveraged multi-island efforts for botanical resources funding. Herein we present our rationale for this collaborative and detail our progress toward creating archipelago-wide groups comprising the Invasive Plant Management Network, Plant Extinction Prevention Program, Native Plant Restoration Program, Integrated Biodiversity Information System, and Work Share Program.
\end{abstract}

Resumen.-Después de casi dos siglos de impactos provocados principalmente por vertebrados continentales introducidos, la flora y la vegetación única del archipiélago de las islas de California han sido severamente degradadas. Los próximos desafíos de conservación botánica incluyen la inminente extinción o extirpación de taxones de plantas raras, endémicas e incluso comunes, la invasión de plantas no autóctonas, la pérdida casi total de las comunidades de vegetación insulares únicas y la degradación de una gran cantidad de sitios; todos estos, son problemas demasiado grandes para ser arbordados por una sola entidad. Muchos de los recursos botánicos afectados se encuentran en varias islas y cruzan fronteras políticas. Los administradores de las Islas de las Californias y sus colaboradores continentales formalizaron una colaboración binacional, conocida como las Islas de las Californias, Colaboración Botánica o Colaboración Botánica de las Islas de las Californias (ICBC, por sus siglas en inglés), para enfrentar estos desafíos de manera más efectiva y eficiente, y así lograr un mayor éxito de conservación. La ICBC ha identificado y priorizado desafíos en la gestión de recursos botánicos, ha llevado a cabo acciones para recuperar poblaciones de plantas en riesgo y prevenir extinciones futuras, ha desarrollado herramientas para evaluar las reintroducciones de plantas, ha implementado reuniones trimestrales para compartir experiencias profesionales, ha comenzado a desarrollar herramientas para compartir información y datos, y ha impulsado labores multi-islas para recaudar fondos para los recursos botánicos. En este artículo, presentamos nuestros fundamentos para esta colaboración y progreso, con el propósito de crear una Red de Gestión de Plantas Invasoras en todo el archipiélago, un Programa de Prevención de Extinción de Plantas, un Programa de Restauración de Plantas Nativas, un Sistema Integrado de Información sobre Biodiversidad y un Programa de Trabajo Compartido.

Conservation of and research on the botanical resources of the Islands of the Californias have been ongoing for over a century (Trask
1899, Junak et al. 1993, Junak 2008, Carter 2015), pursued earnestly by a small but dedicated cadre of scientists and land managers

*Corresponding author: william.hoyer@navy.mil 
over the last 2 decades. As the most urgent animal threats to both flora and fauna have been eliminated or abated, there has been a growing interest in the conservation of the botanical resources. Nearly all mainland introduced vertebrates such as sheep, goats, cattle, deer, rats, and rabbits have been removed from most islands (Aguirre-Muñoz et al. 2011, Jones et al. 2016, McEachern et al. 2016), and the vegetative response has been astounding in many locations (Van Vuren et al. 2012, Beltran et al. 2014, Luna-Mendoza et al. in press). Releasing the flora from browsing and grazing pressure has resulted in a generally positive shift from once-bare soil or nonnative Mediterranean-dominated annual grasslands to native scrub and chaparral-dominated vegetation communities. These recovered vegetation communities are often dominated by endemic plant taxa; however, a suite of invasive plant species have also responded favorably, often outcompeting native plants for resources (Klinger et al. 2002, Corry et al. 2009). On some islands, invasive plant species are dominant over a large part of the island.

Following the removal of introduced mainland vertebrates, there have been both winner and loser endemic plant taxa. Some species like the Santa Cruz Island silver lotus (Acmispon argophyllus var. niveus), which was a species of special concern in 1995 (Junak et al. 1995), have become a common sight in scrub habitats. Yet other species, like island barberry (Berberis pinnata ssp. insularis), beach spectaclepod (Dithyrea maritima), and Lyon's pentachaeta (Pentachaeta lyonii), have been reduced to just a few small populations or even individuals, and are functionally extinct, no longer playing significant roles in ecosystem function.

Now that recovery is in process, island managers need to address the increasing impacts of climate change. Removing introduced vertebrates on an island is akin to putting out a fire, where actions can be clear and resolute; managing for climate change is more like treating an unknown disease with complex symptoms that are hard to identify and anticipate. We do know that ice-age plants such as ironwood trees have gone through climate changes before, although presumably not as quickly as current predictions indicate (Cayan et al. 2008, Diffenbach et al. 2015). Nor were there compounding threats such as invasive species introductions, air pollution, and increased risk of wildfire (Cole et al. 2004, Pyke et al. 2008, Westerling et al. 2008). Now, we ask how climate change will influence recovery and what we can do to preserve the present biodiversity.

Island owners, mainland conservation partners, and scientists of the California Islands met on Santa Cruz Island in the spring of 2014 to discuss the status and future of the islands' botanical resources. This meeting included representatives from The Nature Conservancy (TNC), Channel Islands National Park (CINP), U.S. Navy (USN), Catalina Island Conservancy (CIC), Grupo de Ecología y Conservación de Islas, A.C. (GECI), U.S. Geological Survey (USGS), Santa Barbara Botanic Garden (SBBG), and a suite of other research institutions. The goal was to address common management challenges in this new era where most invasive vertebrates have been removed and climate change is a reality. At this meeting, a thread of common challenges emerged: some rare plants were not recovering, multiple invasive plants had spread and begun taking advantage of the newly reduced grazing and browsing pressure, and no mechanism existed to share botanical information. To address these common challenges collaboratively, we created the Islands of the Californias Botanical Collaborative (ICBC; Islas de las Californias, Colaboración Botánica).

The Santa Cruz Island meeting became an annual event, and the following 2 meetings in 2015 and 2016 were held on San Clemente and Guadalupe Islands, respectively. The ICBC grew to include 18 islands or island groups, the majority of which are in the California Floristic Province, spanning 2 countries (Table 1). In the future, we plan to formalize the ICBC through a letter of intent and/or as a tiered working group under the Canada/ Mexico/U.S. Trilateral Committee for Wildlife and Ecosystem Conservation and Management (https://www.fws.gov/international/wildlife -without-borders/mexico/trilateral-committee .html). This structure will allow us to reach common management goals by formalizing the group and providing a cooperative framework for funding opportunities.

\section{GoALS AND OBJECTIVES}

The ICBC created a long, ranked list of challenges in its initial brainstorming event. 
TABLE 1. Islands and land managers of the Islands of the Californias Botanical Collaborative.

\begin{tabular}{ll}
\hline Island & Botanical land manager \\
\hline Farallon Islands & U.S. Fish and Wildlife Service \\
Ano Nuevo & California State Parks \\
San Miguel & Channel Islands National Park \\
Santa Rosa & Channel Islands National Park \\
Santa Cruz & The Nature Conservancy \& \\
& Channel Islands National Park \\
Anacapa & Channel Islands National Park \\
Santa Barbara & Channel Islands National Park \\
Santa Catalina & Catalina Island Conservancy \\
San Nicolas & U.S. Navy \\
San Clemente & U.S. Navy \\
Islas Coronado & Comisión Nacional de Áreas \\
& Naturales Protegidas \\
Islas Todos Santos & Comisión Nacional de Áreas \\
& Naturales Protegidas \\
San Martín & Comisión Nacional de Áreas \\
& Naturales Protegidas \\
San Jerónimo & Comisión Nacional de Áreas \\
& Naturales Protegidas \\
Guadalupe & Comisión Nacional de Áreas \\
& Naturales Protegidas \\
San Benito & Comisión Nacional de Áreas \\
Cedros & Naturales Protegidas \\
Natividad & Comisión Nacional de Áreas \\
& Naturales Protegidas \\
& Comisión Nacional de Áreas \\
& Naturales Protegidas \\
\hline
\end{tabular}

These translated into 3 general goals:

1. Manage botanical resources as a single archipelago to prevent further plant extinctions or extirpations and recover plant populations at risk.

2. Share botanical information, including restoration methodologies and technical experience.

3. Leverage the collaboration for funding opportunities.

These goals developed into 5 objectives to create each of the following:

I. An Invasive Plant Management Network

II. A Plant Extinction Prevention Program (aka Operation GREEN THUNDER)

III. An Island Restoration Network

IV. An Integrated Biodiversity Information System

V. A Work Share Program

At the 9th California Islands Symposium in October 2016, a session devoted to the ICBC addressed our goals as well as prior management accomplishments. We discussed the status of invasive plant management, rare plant recovery, and habitat restoration efforts across the California islands. We also presented a poster summarizing our accomplishments and plans for the Integrated Biodiversity Information System. This overview of the ICBC represented dedicated efforts both from countries and from many professionals on the islands, some of which were collaborative and some of which represented a significant portion or contribution of individuals' careers. All of these efforts serve as a foundation for accomplishing our objectives in the future.

\section{I: Invasive Plant Management Network}

Currently, each island manager or island management unit (i.e., owners of one or more islands) has its own prioritization and treatment methods, as well as different resources to support their programs. Invasive plant management will benefit from a multi-island approach that will allow standardized data management, easier identification of new species coming to the islands, and prioritization of an archipelagowide early detection rapid-response program. Our work could be more efficient by sharing management treatment methods and labor sources and by developing priorities in concert. To better focus our efforts, we intend to unify the archipelago within a single Weed Management Unit through the California Department of Food and Agriculture's Weed Management Areas Program. This action will allow us to not only be more coordinated, but also to attract more funding by working regionally instead of competing for funds. For the Baja California Islands, the Comisión Nacional de Áreas Naturales Protegidas (CONANP) manages island invasive plant issues, in collaboration with GECI and other entities.

We will conduct a review of the invasive plant species found on each island and produce an archipelago-wide prioritization scheme. For each species, we will review acreage covered, life history, vectors, ranking on other weed lists, management effort needed, and other factors, which can then be considered through a crossisland lens. Invasive plants that are newly introduced and still within reach of eradication on multiple islands through traditional 
methods can be targeted before they spread to other islands (e.g., Euphorbia terracinia on Santa Cruz Island and San Nicolas Island). We can then share skilled botanists and volunteer labor across the archipelago, as phenology windows open and close across the islands' latitudes.

A northern archipelago-wide Biosecurity Program Plan was developed in June 2013 that includes subplans for islands owned by the USN, CINP, TNC, and U.S. Fish and Wildlife Service (USFWS) (http://www.califor niaislands.net/biosecurityoverview/). Similar biosecurity efforts are conducted in Baja California by CONANP and GECI. These programs include measures for

- prevention of new invasions via all major vectors;

- early detection of invasives with on-island monitoring protocols;

- strategies for rapid response to new invasions; and

- creation and dissemination of education programs.

Biosecurity efforts to prevent the vectoring of new weed seeds to islands will continue to be refined through our collaborations, allowing us to have a coordinated, proactive approach across the archipelago.

Collaborative projects to manage invasive plants on the islands have to date included

- helicopter surveys conducted for both Santa Cruz and Santa Rosa Islands, leveraging project work on each island to aid in reducing flight costs (TNC, CINP);

- removal of approximately 3500 mature eucalyptus trees from SCI since 2013 (CINP, TNC);

- sharing of invasive plant control techniques via quarterly and annual meetings (all groups);

- exchange of staff time for training and work share (TNC, USN, CINP); and

- use of volunteers for invasive plant removal projects (Channel Islands Restoration [CIR], CINP, USFWS, Growing Solutions [GS], and California Institute of Environmental Studies [CIES]).

\section{II: Plant Extinction Prevention Program}

The archipelago is home to many rare and endemic plants. Since the end of ranching and agriculture on the California islands and the recent removal of nearly all introduced vertebrate herbivores and omnivores, vegetation recovery has begun. However, recovery is not equal among the surviving plant taxa on the islands. Some taxa are recovering quickly, while others remain rare or underrepresented, even if there is evidence suggesting they were historically common (Philbrick 1980, Bruce 2015). Some taxa are reduced to such low numbers that they cannot rebound through passive restoration as other taxa have done. These taxa may still hold the potential to fill key niches within the island ecosystems. As soils recover, restoration techniques develop, and climate change alters growing conditions into the future, rare plants could become abundant enough to play a key role in ecosystem function. Therefore, saving rare plants is a priority, allowing island managers to maintain biodiversity and presumably build ecosystem resiliency into the future.

Rare plant monitoring has been conducted for decades by the USGS, CINP, SBBG, GECI, San Diego Natural History Museum (SDNHM), and the Universidad Autónoma de Baja California (UABC), among others. To combat extinction, we are building an archipelago-wide rare plant priority list, "the rarest of the rare," to coordinate our efforts. A wealth of rare plant knowledge is housed separately within each institution, from listed plants across the Channel Islands National Park (CINP) to the few remaining California juniper (Juniperus californica) trees on Guadalupe Island. We have begun combining this knowledge to share data on preferred habitat, population demographics and trends, life history, and community ecology information. Multiple threats and challenges have been identified through this work, such as nonnative species invasions, disturbance regime changes, past biological control agent introductions, erosion, climate changes, potential lack of pollinators, and even possibly the cessation of Native American activities such as burning land and harvesting geophytes. For some rare plants that are not recovering or declining, such as island barberry (Berberis pinnata ssp. insularis), 
California juniper (Juniperus californica), and island malva (Malva assurgentiflora), restoration and reintroduction methods are needed. These efforts can benefit from our collaborations as well as via reintroduction material, genetic studies, habitat modeling, restoration techniques, and horticultural expertise across the islands, as some plants might be appropriate to move between islands after supportive genetic analysis, and similar habitat models might be shared across islands with similar conditions.

Collaborative rare plant conservation work to date has included

- monitoring, propagation, genetic analysis, restoration planning, and pollination ecology research for the Federally Endangered island barberry, which has only 5-14 known individuals remaining on Santa Cruz Island (TNC, USGS, SBBG, CINP, and Rancho Santa Ana Botanic Garden);

- habitat suitability modeling and expanded surveys for the Federally Endangered island rock cress (Sibara filifolia) on San Clemente, Santa Catalina, and Santa Cruz Islands (USN, CIC, GECI, TNC);

- construction of an on-site native plant nursery on Guadalupe Island and propagation of California juniper (Juniperus californica) (GECI, CINP);

- propagation and outplanting of Santa Cruz Island bush-mallow (Malacothamnus fasciculatus var nesioticus) and Hoffmann's rockcress (Boechera hoffmannii) on Santa Cruz Island (USGS, CINP, GS, TNC, SBBG); and

- Poa thomasii and Malva assurgentiflora outplanting and establishment of multiple populations on San Clemente Island (USN, Soil Ecology and Restoration Group [SERG]).

\section{III: Native Plant Restoration Program}

Active habitat restoration is necessary to conserve biodiversity on degraded land across the islands, but such restoration is very costly and is particularly logistically complex on islands. By working as one entity across the islands, we can learn from each other's successes and failures and share resources when possible, thus mitigating some of the challenges. The majority of the 18 islands of the California archipelago have active restoration projects underway with the goal of recovery, protection, and conservation of native species and habitats. Examples of some collaborative projects include

- the design of a new nursery on Guadalupe Island via a collaboration between GECI and CINP (with support from the Montrose Settlements Restoration Program [MSRP], CONANP, and Comisión Nacional Forestal [CONAFOR]);

- restoration of seabirds and their nesting habitat through social attraction techniques and vegetation recovery on Santa Barbara, Santa Cruz, Anacapa, Año Nuevo, and the Baja California Islands (CINP, GECI, CIES, GS, USGS, USFWS, Oikonos, and MSRP);

- restoration of maritime cactus scrub, research for restoration of crystalline iceplant (Mesembryanthemum crystallinum)-dominated areas, and biological soil crust restoration on San Nicolas Island (USN, SBBG, CIR, and Northern Arizona University);

- nonnative plant control and restoration on Santa Barbara, Santa Cruz, Anacapa, San Clemente, the Baja Calfornia Islands, and the Farallon Islands (TNC, CINP, USFWS, GECI, USN, and SERG);

- oak restoration on San Clemente Island (USN and SERG); and

- use of fog drip for supplemental watering of upland plantings on Santa Rosa Island (USGS, CINP, and Mountains Restoration Trust [MRT]).

The most important action that we will take in the future is to create a database of restoration projects, which will include both horticultural and project information. The horticultural portion will include information such as seed collection, propagation techniques, greenhouse designs, soil mixes, pot dimensions, and biosecurity best management practices. Project information will include restoration locations, dates, species mixes, outplanting methods, success criteria, and monitoring results. This database will also enable us to better demonstrate the outcomes of our restoration projects and to conduct meta-analyses to learn more about which 
techniques are more effective. Analyses that consider plant traits or ecological networks will help us to be more sophisticated in our restoration planning, implementation, and monitoring, as well as allow for better adaptive management.

\section{IV: INTEGRATED BIODIVERSITY INFORMATION SYSTEM}

The land managers of all 8 California Channel Islands, as well as the Baja California Islands, have together identified data sharing as a top priority for improving conservation management. Data sharing can help set meaningful priorities-a recovery program for the rarest plants across all of the islands, for example, or eradication of a weed across the whole archipelago. It can help us to protect against introduction of our neighbors' invasive species, or to plan a rare plant species' reintroduction from one island to another. Furthermore, by sharing experiences we can avoid duplication of efforts, learn from each other's failures, and build on each other's successes, thereby going farther, faster.

Regular information sharing is currently difficult due to the islands having different managers. Even when data are shared, they have often been collected with different methods, at different scales, or in different formats. Some exist as nondigitized gray literature or handwritten field notes from our predecessors. This is not just work from decades ago but may also include contract deliverables from as recently as a year ago. As employees rotate and program priorities change, keeping the combined knowledge of the taxa on the ICBC will become even more critical.

Together with the National Center for Ecological Analysis and Synthesis (NCEAS), we have initiated the creation of a database with an associated front-end interface linking the disparate data sets across the ICBC. This common database and associated web portal, constituting an "Integrated Biodiversity Information System," will provide a solution to our data-sharing problem across the California islands, resulting in greater management efficiency and informed decision making at the single island scale.

As we build this information system, we plan to share a whole variety of botanical data, including rare and invasive plant distributions and control efforts, vegetation alliances and distributions, genetic information, propagation techniques, restoration metadata, and wildlife relationships (e.g., pollinator-plant networks). We envision a relational database stemming from an all-islands flora table that includes plant traits such as life form and phenology, as well as distributional information. Eventually, we envision an all-taxa information system that includes wildlife, lichens, bryophytes, and more. For now, we are starting with the following 5 priorities:

1. Establishing the core of our information system by serving island botanical specimen data on the online portal Symbiota, where it will be searchable by taxon, island, frequency, watershed, and other features;

2. Sharing metadata regarding existing island data sets and how to access them;

3. Conducting "data rescue" to scan and archive hard copy documents and pursuing raw data from past island scientists while they can still be accessed;

4. Picking example species and putting them through a workflow for the bigger database plan, which will help us choose data standards and establish a proof of concept as well as cost estimates for future funding proposals;

5. Selecting existing databases and setting data collection standards, so that data can be easily integrated later.

The system will be accessible through a custom online search portal that permits participating island landowners to query continuously updated, quality-controlled biodiversity data in a comparable format. The information system will continually evolve to encompass new data as it is generated and collated. The result will be a powerful tool that will allow agencies to efficiently and effectively manage the native biota of their islands in the face of mounting conservation challenges with a flexible, up-to-date, and well-curated common source of information.

\section{V: Work Share Program}

Remote islands have many logistical challenges, including transportation to and from the island as well as limited on-island room 
and board, transportation, supplies, and communication. These logistical challenges coupled with limited program funding, remote worksites, unpredictable weather, and tight survey windows make supporting a skilled workforce difficult. Our solution is to start a work share initiative in the manner of a traditional barn raising, pulling assistance from ICBC members in times when we require expertise and boots on the ground but do not have funds or time for a formal contract. Some tasks are greatly sped along or only possible with a larger group. Such efforts include rare plant surveys, seed collection efforts, invasive plant control, and plant propagation or outplanting. Leaving your place of work for a few days a year gains you a large group of workers at your own program's disposal when you need it most.

We have found work sharing to be very effective and have utilized it for rare plant surveys on Santa Cruz and San Clemente Islands, invasive species surveys on San Nicolas and Santa Catalina Islands, restoration outplanting on Santa Barbara and Anacapa Islands, as well as vegetation mapping on San Miguel and Santa Cruz Islands. Support from supervisors is more readily given when work sharing is formalized in a written agreement. Agreements can follow formal volunteer guidelines or be modeled after professional exchange programs, depending on the ICBC member. Work sharing various infrequent tasks such as vegetation mapping can keep island botanists updated in their skill sets and in interpreting methodologies uniformly.

\section{Collaboration Challenges AND OPPORTUNITIES}

A successful collaboration of this size and diversity is challenging but fruitful. Each member works for an organization with different constraints to contend with and capabilities to offer. Obstacles we are still working on include scheduling meetings in different locations so as to spread the burden of travel expenses, deciding which members will take on what portions of work from grants we collectively apply for, and writing up MOAs between agencies and cooperative agreements between landowners and practitioners to allow closer working ties. As we continue to incrementally accomplish more of our goals and objectives, new challenges appear, but fewer seem as novel or difficult to overcome. We find that making the decision process as transparent as possible creates more discussion up front, but keeps stakeholders' expectations realistic.

We built the ICBC for opportunities we saw in botanical management as a single entity, and these opportunities have played out in multiple ways since our inception. There is much better communication between the stakeholders; we are communicating more openly, which has allowed us to tackle regional issues in ways that were previously not thought possible. A great example was our latest success in obtaining funding for monitoring and restoring over a dozen species of endangered plants across multiple islands and island managers, a feat that would not have been possible only a few years ago due to a lack of organization amongst the required stakeholders. The ICBC will continue to create more opportunities through working together and finding more efficient and effective means by which we can recover the flora of the Islands of the Californias.

\section{CONCLUSION}

Benefits of the ICBC have already started to materialize since our first meeting in 2014 , through the selection and pursuance of our goals and objectives. The act of focusing on objectives and reforming our quarterly meetings around them has tapped the strengths of every member and agency. These meetings have resulted in a beneficial sharing of information on invasive plant control, germinated successful multi-island rare plant funding proposals, and promoted a better understanding of each island's management challenges between ICBC participants. The Integrated Biodiversity Information System is in the works with academic collaborators and promises to be a powerful management tool for plants and other organisms. Our future may hold droughts, invasive plants, and other botanical bedlam, but we will face it collaboratively and as a single archipelago with much strength.

\section{Literature Cited}

Aguirre-Muñoz, A., A. Samaniego-Herrera, L. LunaMendoza, A. Ortiz-Alcaraz, M. RodríguezMalagón, F. MÉndeZ-SÁnchez, M. FÉlix-LizárRaGa, J.C. Hernández-Montoya, R. González-Gómez, F. TorRes-GarCía, AND J.M. BARREDO-BARBERENA. 2011. Island restoration in Mexico: ecological outcomes after 
systematic eradications of invasive mammals. Pages 250-258 in Island invasives: eradication and management, Auckland, New Zealand, 8-12 February 2010. IUCN, Gland, Switzerland.

Beltran, R.S., N. Kreidler, D.H. Van Vuren, S.A. Morrison, E.S. Zavaleta, K. Newton, B.R. Tershy, AND D.A. CROLL. 2014. Passive recovery of vegetation after herbivore eradication on Santa Cruz Island, California. Restoration Ecology 22:790-797.

BRuCE, S. 2015. Report on historic vegetation communities of San Clemente Island. Washington College, unpublished. Prepared for Dawn Lawson, U.S. Navy, SPAWAR Command, San Diego, CA.

CARTER, B.E. 2015. A checklist of the bryophytes of the California Channel Islands. Madroño 62:186-207.

Cayan, D.R., E.P. Maurer, M.D. Dettinger, M. Tyree, AND K. HaYhoE. 2008. Climate change scenarios for the California region. Climate Change 87:S21-S42.

Cole, M.A., And E. Neumayer. 2004. Examining the impact of demographic factors on air pollution. Population and Environment 26:5-21.

Corry, P.M., AND A.K. McEachern. 2009. Patterns in post-grazing vegetation changes among species and environments, San Miguel and Santa Barbara Islands. Pages 201-214 in Proceedings of the 7th California Islands Symposium, Oxnard, USA, 5-8 February 2008. Institute for Wildlife Studies, Arcata, CA.

Diffenbach, N.S., D.L. Swain, and D. Touma. 2015. Anthropogenic warming has increased drought risk in California. Proceedings of the National Academy of Sciences 112:3931-3936.

Jones, H.P., N.D. Holmes, S.H.M. Butchart, B.R. Tershy, P.J. Kappes, I. Corkery, A. Aguirre-Muñoz, D.P. Armstrong, E. Bonnaud, A.A. Burbidge, Et AL. 2016. Invasive mammal eradication on islands results in substantial conservation gains. Proceedings of the National Acadamy of Sciences 113: 4033-4038.

JunAK, S. 2008. A flora of San Nicolas Island, California. Santa Barbara Botanical Garden, Santa Barbara, CA.

Junak, S., T. Ayers, R. Scott, D. Wilken, and D. Young. 1995. A flora of Santa Cruz Island. Santa Barbara Botanic Garden and the California Native Plant Society, Santa Barbara, CA.

Junak, S., R. Philbrick, and C. Drost. 1993. A revised flora of Santa Barbara Island: an annotated catalog of the ferns and flowering plants and a brief history of botanical exploration. Santa Barbara Botanical Garden, Santa Barbara, CA.

Klinger, R.C., P. Schuyler, and J.D. Sterner. 2002. The response of herbaceous vegetation and endemic plant species to the removal of feral sheep from Santa Cruz Island, California. Pages 141-154 in Turning the tide: the eradication of invasive species, Auckland, New Zealand, 19-23 February 2001. IUCN, Gland, Switzerland.

Luna-Mendoza, L., A. Aguirre-Muñoz, F. MéndezSánchez, J.C. Hernández-Montoya, N. SillvaEstudillo, B. Bermúdez-Almada, J.S. GarcíaCarreón, D. Cosio-Muriel, O. Puebla-Hernández, and S. Luvianos-Colín. In press. Ten years after feral goat eradication: the active restoration of plant communities on Guadalupe Island, Mexico. In: Proceedings of the Island Invasives Conference, Dundee, Scotland, 10-14 July 2017 . IUCN.

McEachern, K., T. Atwater, P. Collins, K. Faulkner, AND D. Richards. 2016. Managed island ecosystems. Pages 755-778 in H. Mooney and E. Zavaleta, editors, Ecosystems of California. UC Davis Press, Davis, CA.

Philbrick, R. 1980. Distribution and evolution of endemic plants of the California islands. Pages 173-188 in The California islands: proceedings of a multidisciplinary symposium. Santa Barbara Natural History Museum, Santa Barbara, CA.

Pyke, C.R., R. Thomas, R.D. Porter, J.J. Hellmann, J.S. Dukes, D.M. Lodge, and G. Chavarria. 2008. Current practices and future opportunities for policy on climate change and invasive species. Conservation Biology 22:585-592.

Trask, B. 1899. Field notes from Santa Catalina Island. Erythea 7:135-146.

VAN Vuren, D.H., and L. Bowen. 2012. Response of grassland and vegetation on Santa Cruz Island to removal of feral sheep. Madroño 59:190-195.

Westerling, A.L., AND B.P. BRYant. 2008. Climate change and wildfire in California. Climatic Change 87 (Supplement 1):S231-S249.

Received 2 March 2017

Revised 28 November 2017

Accepted 26 January 2018

Published online 14 November 2018 